\title{
KÉSŐ RÓMAI POHÁRFORMÁK PANNONIÁBAN
}

\author{
DÉVAI KATA*
}

The study offers the slim beakers with curving body, slim beakers with curving wall and a base ring, slim, cylindrical beakers and slim, cylindrical beakers with a base ring. These all can be related to one workshop on the grounds of their same qualities, colours, measures, decorations, rims, and their chronological and geographical spread. The workshop may have operated at the end of the 3rd century $A D$, rather in the first half of the 4th century $A D$.

Keywords: late Roman period, Pannonia, glass vessels, glass beakers, cemeteries

Jelen tanulmány a karcsú, ívelt falú talpgyürüs és talpgyürü nélküli, valamint a magas hengeres testü talpgyürüs és talpgyürü nélküli pohárformákkal foglalkozik, amelyek azonos minőségük, szinük, méretük, megmunkáltságuk, valamint időrendjük és területi elterjedésük alapján valószinüleg egy mühelykör termékei lehettek. A mühely a 3. század végén vagy inkább a 4. század elején müködhetett.

Kulcsszavak: késő római kor, Pannonia, üvegedények, üvegpoharak, temetók

Barkóczi László 1988-ban megjelent katalógusában elemezte Pannonia üvegmúvességét. Öt korszakra osztja a provincia üvegedény-használatát. Az első évszázadokra az importedények jelenléte jellemző, és megfigyelhető az üvegek fokozatos elterjedése előbb a Borostyánkő út, majd a limes mentén fekvő településeken. A Kr. u. 1-2. évszázad üvegedényei részben kereskedelmi cikként jelennek meg a tartományban. ${ }^{1} \mathrm{Az}$ unguenta-

A kézirat érkezett: 2016. május 4.

* Dévai Kata, MTA-ELTE BTK Interdiszciplináris Régészettudományi Kutatócsoport (MTA-ELTE Research Group for Interdisciplinary Archaeology). H-1088 Budapest, Múzeum krt. 4/b, Hungary; kata.devai@gmail.com.

1 A hazai üvegkutatás feladata annak kimutatása, hogy a kereskedelmi cikként megjelenő üvegedényeket mikor váltják fel a pannoniai készítésú példányok, valamint az import és helyi gyártmányok a tartomány életében mikor, milyen arányban voltak használatban. riumoktól és az urnáktól eltekintve, amelyek nagy népszerüségre tettek szert, a többi edényforma (asztali használatra szánt edények és tárolásra szolgáló palackok) használata nagy szériákban nem mutatható ki a korai évszázadokban. ${ }^{2}$ A 2. század végén, a 3. század elején azonban már bizonyosan múködtek üveggyártó múhelyek Pannoniában is. Legkésőbb ettől kezdve az üvegedényeket nagyrészt helyi gyártmányoknak tarthatjuk. ${ }^{3}$ A 3. század vége és a 4 . század első harmada közé eső időszakban Pannonia leletei között új formák túnnek fel. A korábbi alacsonyabb, szélesebb poharakat felváltják a magasabb, nagyobb ürtartalmú edények. ${ }^{4}$ A 3 . század végén, a 4. század elején kezdődik Pannonia üveggyártásának legvirágzóbb időszaka: többnyire színtelenített, jó minőségú alapanyagból

\footnotetext{
BARKÓCZI 1988, 20-23.

DÉVAI-GELENCSÉR 2012, 439-468.

BARKÓCZI 1988, 23.
} 
leginkább helyi múhelyekben készült, változatos és jól használható üvegedények sorozatai jelennek meg. ${ }^{5}$ A késő római időszakban megfigyelhetó tendencia, hogy a határ menti provinciák leletanyagában az üvegedények igen nagy hányadát a poharak teszik ki - e sorozatba illeszkednek a pannoniai leletegyüttesek is. ${ }^{6}$ A vizsgált időszakban, a 3. század végén, 4 . század elején négy pohártípus válik különösen kedveltté, az ívelt falú talpgyưrüs és talpgyưrú nélküli (P1 és P2), valamint a hengeres testú talpgyưrüs és talpgyưrú nélküli formák (P3 és P4). Mind a négy karcsú, nagyméretú, a hétköznapi életben is jól használható edényforma, ${ }^{7}$ amely kiszorította a korábban népszerú, jóval alacsonyabb, szélesebb, a csészékre inkább hasonlító üvegpohártípusokat. Mivel mind a négy formából egész sorozatok jelentek meg, ezért lehetőség volt ezek tér- és időbeli elterjedésének vizsgálatára is, ami a méretük, alapanyaguk, megmunkáltságuk összehasonlításával lehetőséget nyújtott múhelykörhöz kötésükhöz is.

\section{Magas, ívelt falú pohárforma (P1 típus) ${ }^{8}$}

A négy közül a magas, ívelt falú forma a legelterjedtebb. Különlegessége, hogy Pannonián kívül ritkán fordul elő. A Római Birodalom más részein inkább a magas, hengeres testú üvegpoharak kedveltek. Egy-egy példánya Pannonia déli, ma Szerbiához tartozó részéról is ismert. ${ }^{9}$ Vindobonában a 4. és kora 5. századi, helyi gyártmánynak tartott változatok között szerepel, amelyet jellegzetesen vágott peremkialakítással készítettek színtelenített vagy zöldes, rossz minőségú alapanyagból. ${ }^{10}$ Pannonián kívül Dalmatiában is feltúnik. ${ }^{11}$ A Római Birodalom területéról hasonló darabok az augsti leletanyagban és Colchesterben fordulnak elő. Augstban szabadon fújt, kónikus, pontosan nem meghatározható formájú darabokként tartják számon. ${ }^{12} \mathrm{~A}$ hengeres testúként leírt

5 BARKÓCZI 1988, 23-25; DÉVAI 2012.

6 VAN LiTH-RANDSBORG 1988, 458; DÉVAi 2012. Doktori disszertációmban a vizsgált 4-5. századi időszak 987 síredénye közül 453 pohárforma (a teljes anyag 44,57\%-a). A megjelölt időszak elején a domináns ívelt falú és hengeres testú pohárformák az összes általam vizsgált pohár több mint 20\%-át (91 $\mathrm{db})$ teszik ki.

7 DÉvAi 2012, 233-240. A késő római magas poharak (ívelt falú, hengeres testú, kúpos testú típusok) úrtartalma $200-250 \mathrm{~cm}^{3}$ közé tehető.

8 DÉVAI 2013, 260-264.

9 RUŽıć 1994, T. XXXVIII.2.

0 SAKl-Obertahler-Tarcsay 2001, 96, Taf. 5.47A

CERMANOVIĆ-KuZMANOVIČ 1979, Tab. IV.

2 RÜTTI 1991, Taf. 70. 1517-1520. néhány colchesteri töredék perem- és aljkiképzése alapján sorolható ide. ${ }^{13}$

Barkóczi katalógusában ebbe a kategóriába tartoznak a 44. és 45. típusba sorolt üvegek. A 44. szám alatt egy 3. század végére, 4 . század elejére keltezhető brigetiói sírból magas, ívelt falú pohár szerepel, kihajló, vágott peremmel, enyhén benyomott aljjal, de Intercisából is ismert hasonló darab. ${ }^{14}$ A következő, 45 . forma a 4. század második felére datált, ritkán előkerülő, enyhén hullámos falú edényeket jelöl Brigetióból és Majsról, hasonlóképp kihajló, vágott peremmel, enyhén benyomott aljjal. ${ }^{15} \mathrm{~A}$ két változat formailag nagyon hasonló, megegyezik a peremkialakításuk, erósen kihajló ívelt peremmel és ívelt, de az alj felé nem összeszúküulő formával. Az alj mindkét esetben enyhén benyomott. Azonosságaikat tekintve tipológiai szétválasztásuk indokolatlan.

A késő római temetőkből összesen 40 edény (az összes késő római pohár $8,4 \%$-a) ${ }^{16}$ sorolható a P1 típusba (1. kép 1-9; 2. kép 1-5; 4. kép 1-2). Brigetio területéről négy, Aquincumból, a Bécsi úti temetőből hat, a Pasaréti útról egy, MórichidaKisárpás temetójéből négy, Győr-Főügyészség, Győr-Szent István utca és Győr-ETO kézilabdapálya lelőhelyekről három, Mosonszentmiklósról négy, Esztergomból, a Kossuth utca temetôjéből három, Pécsról öt, Majsról, Ságvárról, Keszthelyről egy ívelt falú, magas pohár ismert. ${ }^{17}$

\section{Anyag, méret}

Három-három üvegzöld és sárgászöld, valamint egy mohazöld edény kivételével mindegyik színtelen, de változó minőségú üvegből készült, az alapanyag gyakran buborékokkal, húzódásokkal telt. Méreteit tekintve a csoport egységes. A poharak magassága 10-11,3 cm közötti, szájátmérójük 6,7-8 cm között mozog, a talpátmérő 3,9-4,8 $\mathrm{cm}$. (Kivételt képez két kisebb méretü - 7,7 és 9 cm magas -, de egyező formájú aquincumi darab; a magasságát tekintve $-14,2 \mathrm{~cm}$ - kivételt képez a brigetiói Faltenbecher is.)

\section{Perem-és aljkialakitás}

Peremük erősen ívelt, vágott és durva felszínú, kialakításuk eldolgozatlan. Négy pohár eltér ettől a megmunkálási módtól, Mosonszentmik-

13 CoOl-Price 1995, 69, Fig. 5.3.335.

14 BARKÓCZI 1988, 79.

15 BARKÓCZI 1988, 79-80.

16 Dévai 2012. P1 forma, Kat. Nr. 24-63, XXVI. tábla/131-133. kép.

17 BARKÓCZI 1961, 95-115; BARKÓCZI 1968, 59-86, 5., 11., 15. sír; TopÁl 1993, 9., 18-20., 24., 32. sír; BUdAI-BALOGH 2008, 40-56; Kelemen 2008, 31., 48. sír; Dévai 2012, Kat. Nr. 24-63. 

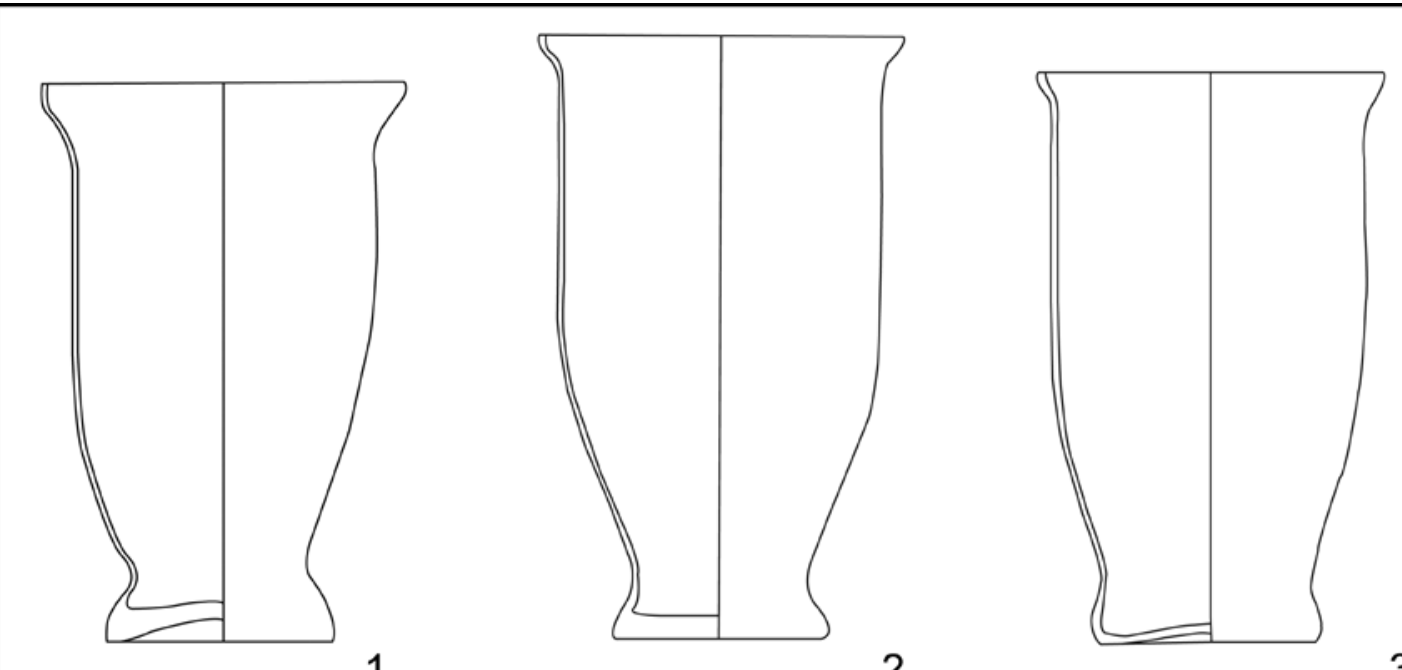

2
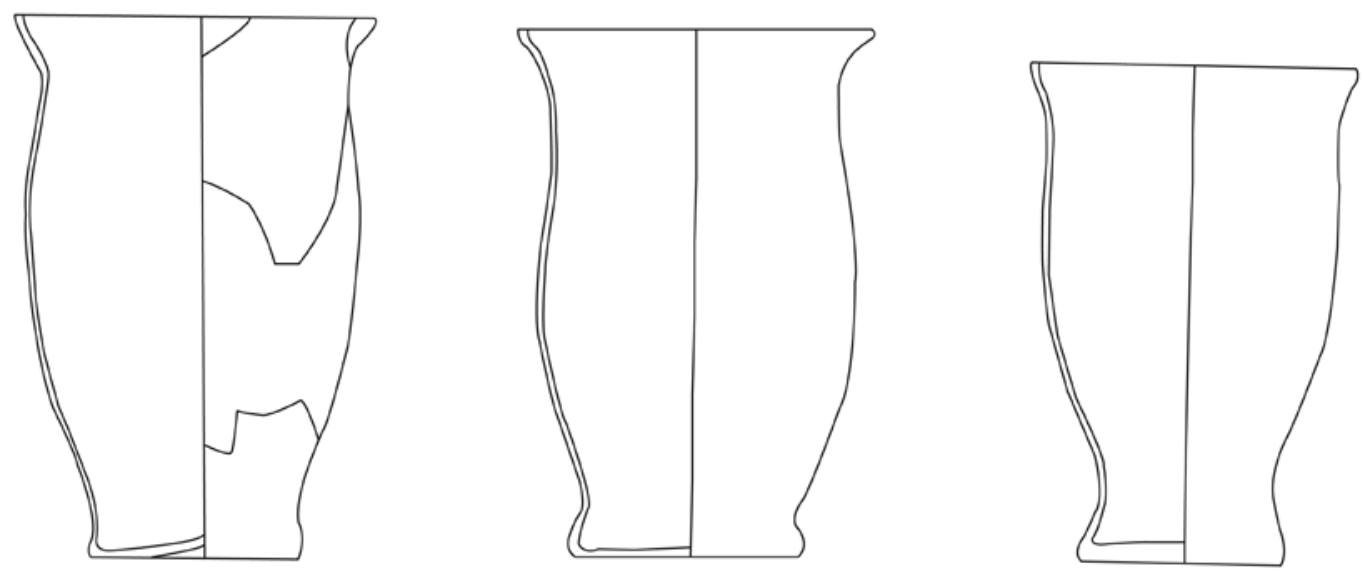

4

5

6
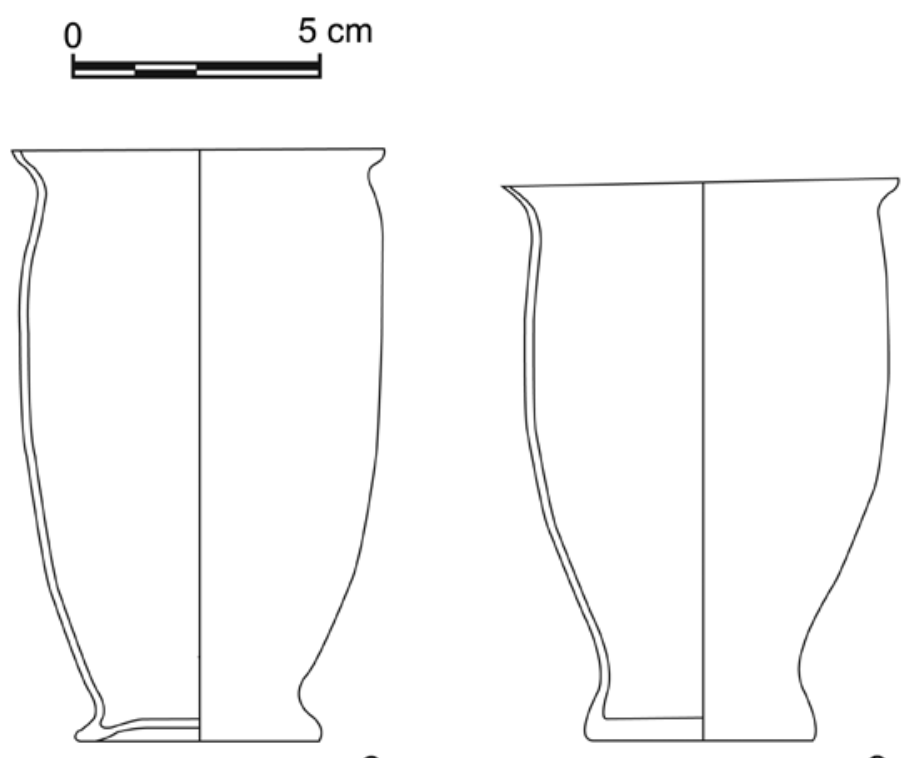

7

8

1. kép. Ívelt falú poharak. 1-5: Budapesti Történeti Múzeum-Aquincumi Múzeum. Ltsz.: 2007.11.9., 91.2.114., 91.2.125., 91.2.85., 92.1.15; 6: Győr, Xántus János Múzeum. Ltsz.: 65.3.1; 7: Esztergom, Balassa Bálint Múzeum. Ltsz.: 96.68.1; 8-9: Budapest, Magyar Nemzeti Múzeum. Ltsz.: 59.1.13, 59.1.2.

Fig. 1. Slim beakers with curving body. 1-5: Budapesti Történeti Múzeum-Aquincumi Múzeum; 6: Győr, Xántus János Múzeum; 7: Esztergom, Balassa Bálint Múzeum; 8-9: Budapest, Magyar Nemzeti Múzeum 

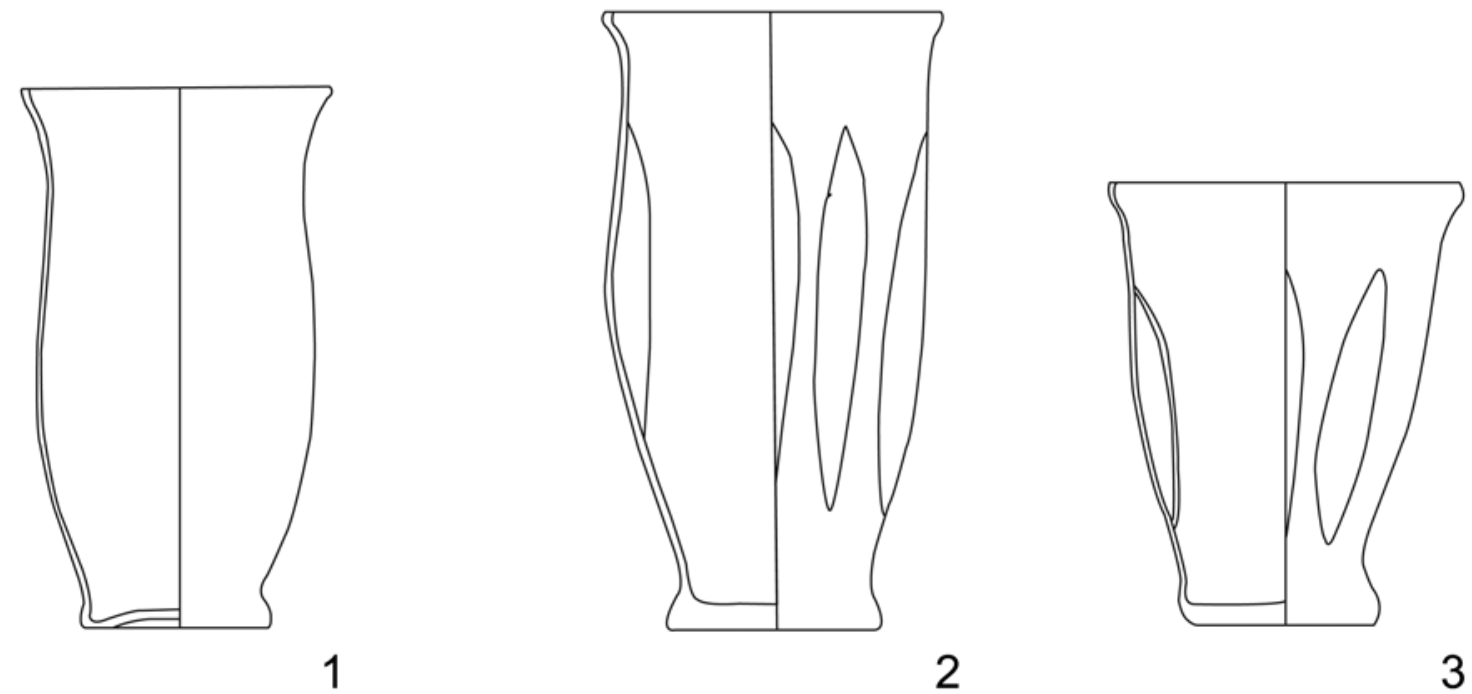

1

2

3
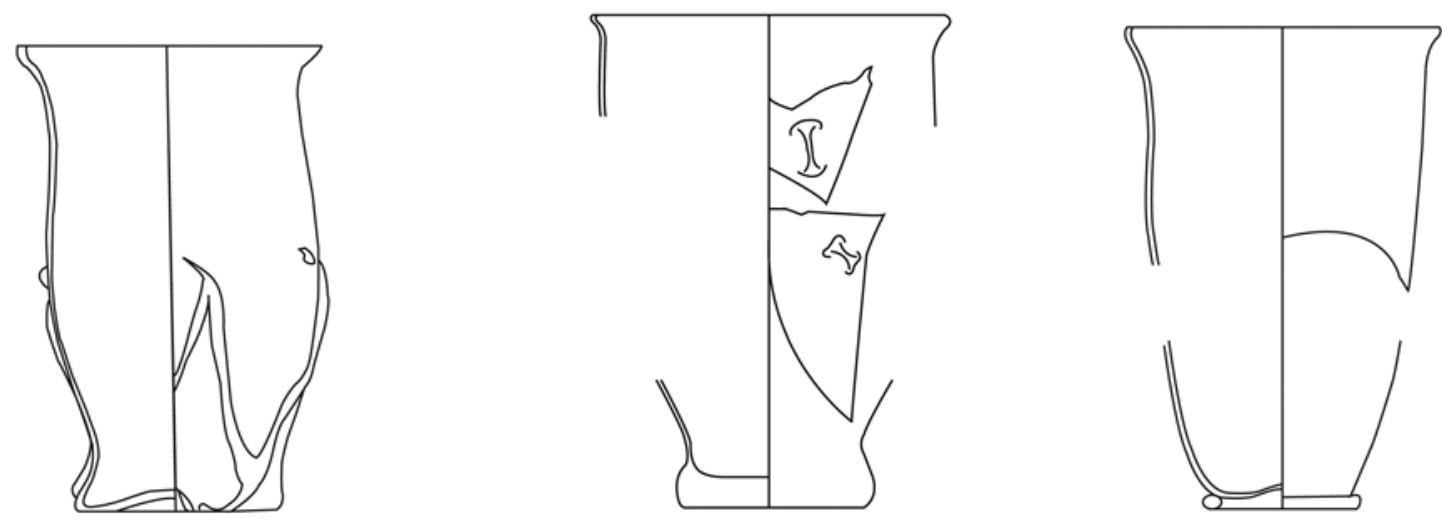

5

6
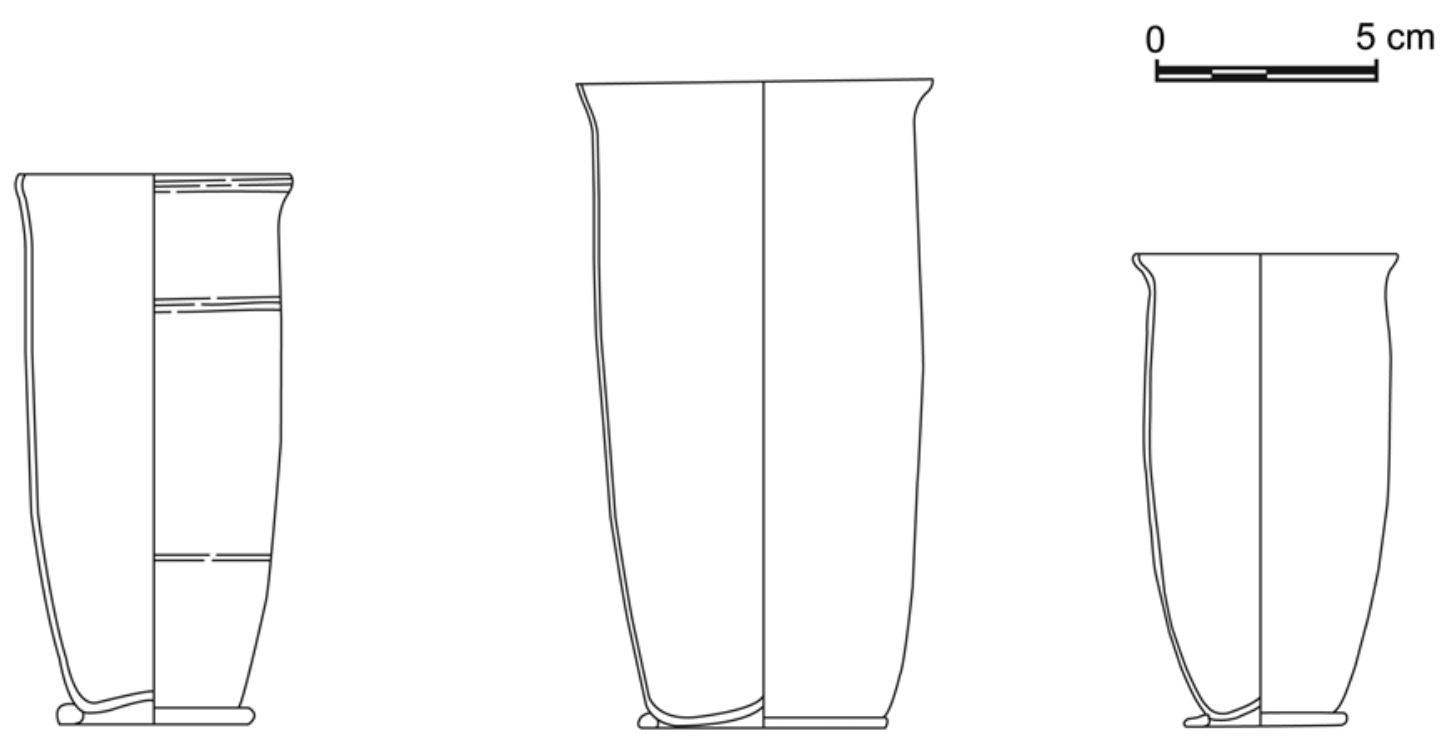

7

8 
2. kép. 1: ívelt falú pohár. Győr, Xántus János Múzeum. Ltsz.: 66.39.78; 2-3: ívelt, horpasztott falú poharak. Budapest, Magyar Nemzeti Múzeum. Ltsz.: 60.9.2; Pécs, Janus Pannonius Múzeum. Ltsz.: 69.6.2; 4-5: ívelt falú, díszített poharak. Győr, Xántus János Múzeum. Ltsz.: 2002.1.2; Budapesti Történeti Múzeum-Aquincumi Múzeum. Ltsz.: 83.3.24; 6-9: ívelt falú, talpgyürüs poharak. Pécs, Janus Pannonius Múzeum. Ltsz.: 2004.2.183; Keszthely, Balatoni Múzeum. Ltsz.: 70.268.1; Komárom, Klapka György Múzeum. Ltsz.: M998. II.2; Budapest, Magyar Nemzeti Múzeum. Ltsz.: 59.1.14.

Fig. 2. 1: slim beaker with curving body. Győr, Xántus János Múzeum; 2-3: slim, indented beakers with curving body. Budapest, Magyar Nemzeti Múzeum, Pécs, Janus Pannonius Múzeum; 4-5: slim, decorated beakers with curving body. Győr, Xántus János Múzeum; Budapesti Történeti Múzeum-Aquincumi Múzeum; 6-9: slim beakers with curving wall and a base ring. Pécs, Janus Pannonius Múzeum; Keszthely, Balatoni Múzeum; Komárom, Klapka György Múzeum; Budapest, Magyar Nemzeti Múzeum

lósról erősen ívelt, de melegen lekerekített, enyhén megvastagodó peremú változatot ismerünk. A többi melegen lekerekített, megvastagodó peremú példány Majsról, Keszthely-Dobogóról, Pécsről és Bátaszék-Kövesdről került elő, tehát Valeria déli részéról. Aljuk kivétel nélkül enyhén benyomott, kisebb-nagyobb mértékben megvastagodó. Tartórúd nyoma az esetek körülbelül felében látható.

\section{Díszités}

A magas, ívelt falú poharakat - néhány kivétellel - nem díszítették. ${ }^{18}$ Egy Mórichida-Kisárpásról, valamint egy Ságvárról származó darabon a peremen és az edény testén bekarcolt sáv figyelhetó meg. ${ }^{19}$ Egy Győrből származó üvegen egy az edénnyel megegyező alapanyagból készített, szabálytalan, csúcsos íveket alkotó plasztikus szálrátétet helyeztek el a pohár testének alsó harmadában (2. kép 4; 4. kép 2). ${ }^{20}$ Méreteit, színét, anyagminőségét, megmunkáltságát tekintve a magas, ívelt falú poharak sorába illeszkedik. Pontos párhuzama nem ismert. Hasonló, az edény alsó harmadában elhelyezett, vékony plasztikus szálrátét íves dekorációja van egy montignyi üvegnek, de a pohár hengeres testú, talpgyưrús, a 4 . századra datálható. ${ }^{21}$ Érdekes variáns került elő Aquincumból: a pohár oldalán kicsipkedett minta található, amely különösen ritka a késő római időszakban (2. kép 5). ${ }^{22}$

A díszített változatok csoportjába tartozik két ívelt falú, benyomott oldalú pohár (Faltenbecher) (2. kép 2-3; 4. kép 4). ${ }^{23} \mathrm{~A}$ késő római időszakban e

18 DÉvai 2013, 262-263.

19 Mórichida-Kisárpás: 137. sír. Xántus János Múzeum. Ltsz: 59.24.143; Ságvár: 242. sír. Rippl-Rónai Múzeum Ltsz.: 11.729.1.

20 Xántus János Múzeum. Ltsz.: 2002.1.2.

21 Martin 1993, 100, Fig. 1.3.

22 FADIĆ 1997, 146. Hasonló díszítés található egy Mursából származó gömbtestú palackon, amely az aquincumi pohárral megegyező időszakra, a 4. századra datálható; DÉvAI 2012, Kat. Nr. 58. Budapesti Történeti Múzeum-Aquincumi Múzeum. Ltsz.: 83.3.24.

23 DÉval 2013, 262-263. pohárforma előfordulása ritka. Barkóczi katalógusában a 49. és 50. típus jelöli a horpasztott oldalú poharakat. ${ }^{24} \mathrm{~A}$ vizsgált leletek között két példány horpasztott falú, a Barkóczi katalógusában a „d" változat alatt említett brigetiói darab. ${ }^{25}$ Magas, ívelt falú, oldalán négy benyomással díszített pohár. Enyhén kihajló, vágott, durva peremmel, egyenes, megvastagodó aljjal. Tartórúd nyoma nem látható. Alapanyaga színtelen, közepes minőségú. A pohár színe, anyagminősége és megmunkálása alapján inkább a 4. század első évtizedeire keltezhető. A másik Faltenbecher egy pécsi sírból származik. ${ }^{26}$ Színtelenített, közepes minőségú, ívelt falú üveg. Oldalát öt hosszanti benyomás díszíti. Pereme ívelt, vágott, durva felszínú. Alja egyenes, megvastagodó. Párhuzama - töredékes formában - megtalálható DélPannoniában. ${ }^{27}$ Pontos analógiája nem ismert. Hasonló, horpasztott oldalfalú edény került elő Colchesterben a pereme alatt bekarcolt vonaldísszel kombinálva, enyhén zöldes színben, egyenes, vágott peremmel, a 2. századra keltezve. ${ }^{28}$ Magas, egyenes, benyomott aljú típus tünik fel a karanisi anyagban, de négy széles ovális benyomással. ${ }^{29}$ A Krefeld-Gellep temetőjében talált, benyomott oldalú magas pohár pereme vágott, alatta bekarcolt vonaldísz, feltehetően már a 4.

24 BARKócZi 1988, 86-88. A 49. típus: ovális, talpgyưrúvel ellátott, keltezés: 1. század vége, 2 . század vége; az 50. típus: magas benyomott oldalú poharak talpgyúrúvel; „50a" variáns: hosszúkás forma keskeny aljjal, kihajló, vágott peremmel, keltezés: 1-2. század; "50b” variáns: magas keskeny talpgyưrűs kehelyforma négy nagy ovális benyomással az oldalán, keltezés 3. század (Észak-Itália, Római Birodalom nyugati részei, dunai provinciák), 4. század (Földközi-tenger keleti vidékei); "50c" variáns: keltezése 2. század (Római Birodalom nyugati részei); "50d” variáns: hosszúkás, ívelt falú, oldala négy hosszanti benyomással díszített, nem rendelkezik talpgyưrúvel, habár a forma megnevezésében Barkóczi László "talpgyưrús" jelzőt használ, Brigetióból került elő.

25 Magyar Nemzeti Múzeum. Ltsz.: 60.9.2.

26 Janus Pannonius Múzeum. Ltsz.: 69.6.2.

27 RUŽIĆ 1994, T. XXXVI.3.

28 COOL-Price 1995, Fig. 5.4.390.

29 Harden 1936, Pl. XV. 


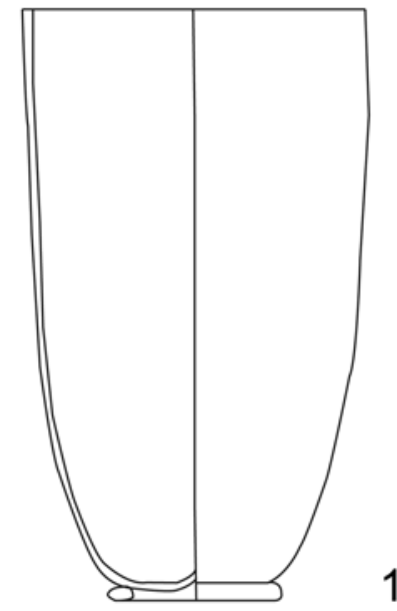

1

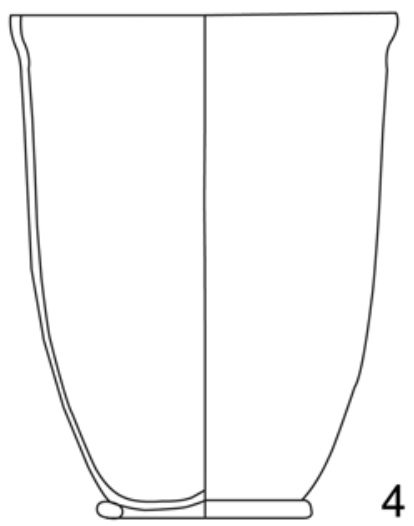

4
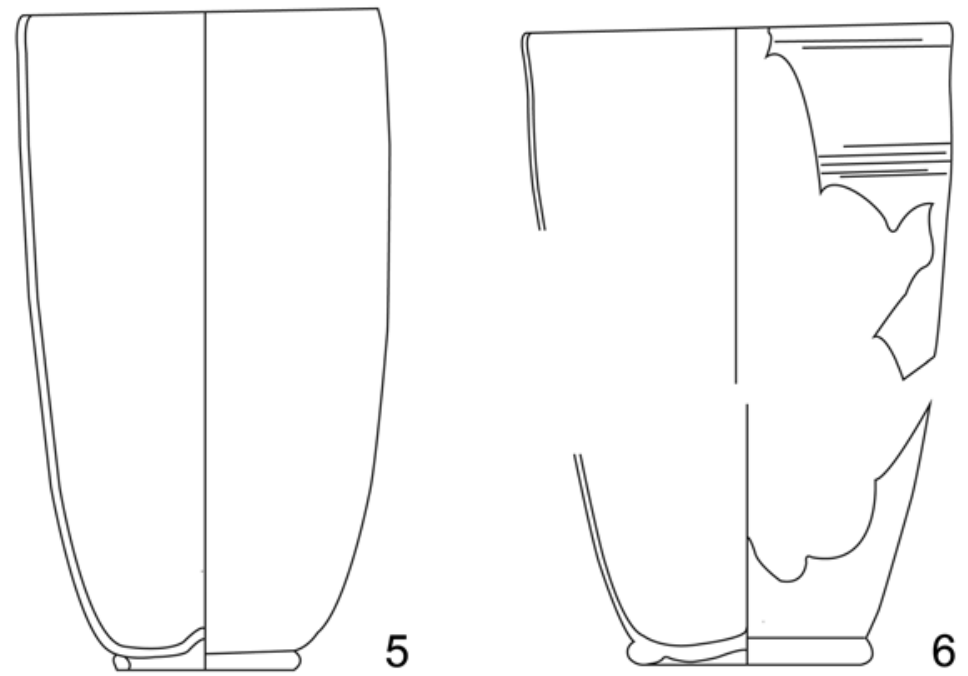

$5 \mathrm{~cm}$
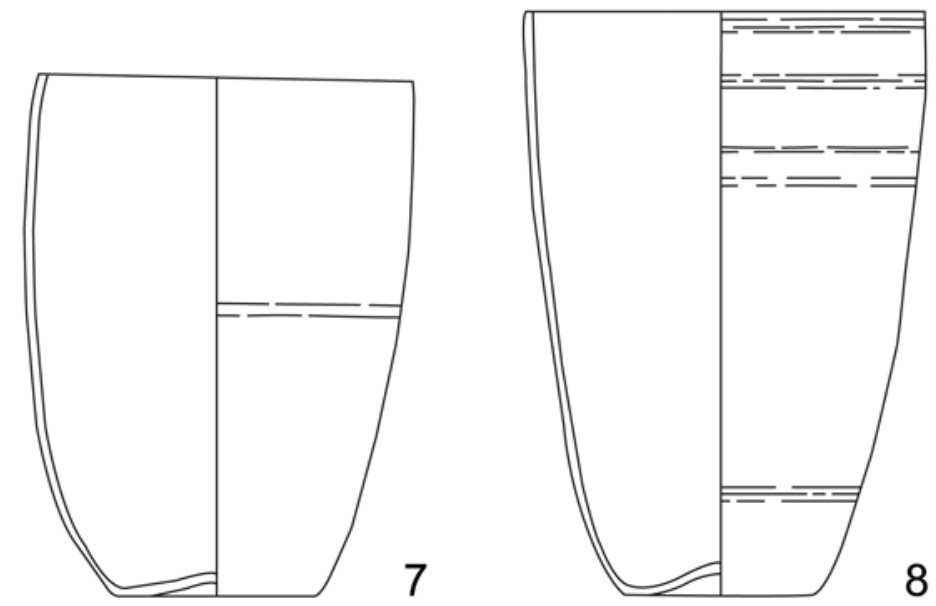

8

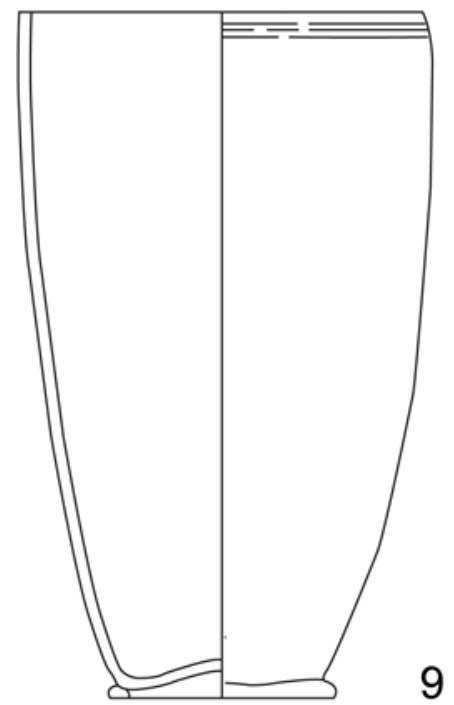


3. kép. 1-6: hengeres testủ talpgyürüs poharak. Budapesti Történeti Múzeum-Aquincumi Múzeum. Ltsz.: 86.7.2., 91.2.2., 91.2.89; Esztergom, Balassa Bálint Múzeum. Ltsz.: -; Szentendre, Ferenczy Múzeum. Ltsz.: -; Komárom, Klapka György Múzeum; 7-8: hengeres testủ, díszített pohár. Pécs, Janus Pannonius Múzeum. Ltsz.: 69.24.2, Győr, Xántus János Múzeum. Ltsz.: 59.24.172; 9: hengeres testủ, díszített pohár talpgyürüvel. Szombathely, Savaria Múzeum. Ltsz.: -

Fig. 3. 1-6: slim, cylindrical beakers with a base ring. Budapesti Történeti Múzeum-Aquincumi Múzeum, Esztergom, Balassa Bálint Múzeum, Szentendre, Ferenczy Múzeum, Komárom, Klapka György Múzeum; 7-8: slim, cylindrical, decorated beakers with base ring. Pécs, Janus Pannonius Múzeum. Györ, Xántus János Múzeum; 9: slim, cylindrical, decorated beaker with base ring. Szombathely, Savaria Múzeum

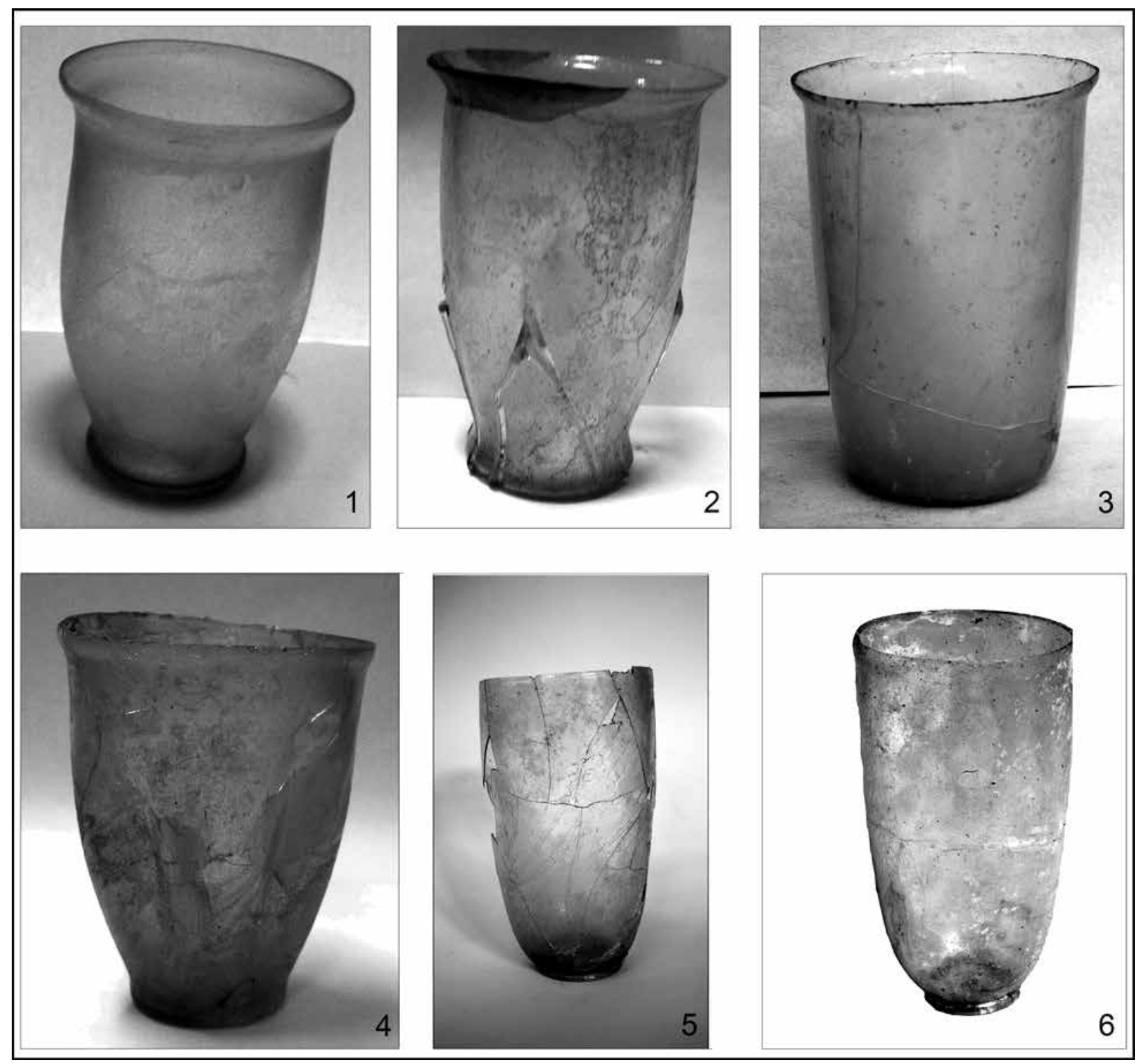

4. kép. 1: ívelt falú pohár. Esztergom, Balassa Bálint Múzeum. Ltsz.: 96.68.1; 2: ívelt falú pohár szálrátétdíszítéssel. Győr, Xántus János Múzeum. Ltsz.: 2002.1.2; 3: hengeres testủ pohár. Komárom, Klapka György Múzeum. Ltsz.: -; 4: ívelt falú, benyomott oldalú pohár. Pécs Janus Pannonius Múzeum. Ltsz.: 69.6.2.; 5-6: hengeres testű, talpgyűrüs poharak. Szombathely, Savaria Múzeum. Ltsz.:-, Budapesti Történeti Múzeum-Aquincumi Múzeum. Ltsz.: 86.7.2 (fotó: Komjáthy Péter)

Fig. 4. 1: slim beaker with curving body. Esztergom, Balassa Bálint Múzeum; 2: slim beaker with curving body and applied trails. Győr, Xántus János Múzeum; 3: slim, cylindrical beaker. Komárom, Klapka György Múzeum; 4: slim, indented beaker with curving body. Pécs Janus Pannonius Múzeum; 5-6: slim, cylindrical beakers with base ring. Szombathely, Savaria Múzeum, Budapesti Történeti MúzeumAquincumi Múzeum 
század elején készültt. ${ }^{30}$ Nagyon hasonló a Montigny területén előkerült, 4 . századra datálható pohár, amelynek azonban megvastagodó, melegen lekerekített pereme és erősen megvastagodó alja van. ${ }^{31} \mathrm{~A}$ birodalom keleti területeiről a ciprusi üveganyagban szerepel ugyanez a forma, de több keskeny, ovális benyomással ékesítve. ${ }^{32}$ Aquileia üveganyagában is fellelhető egy Faltenbecher típus, amely az 1 . századtól a 3. század végéig volt használatban, peremkiképzése kihajló, vágott, alja pedig megvastagodó, de maga az edény szélesebb, alacsonyabb a pannoniai daraboknál. ${ }^{33}$ Italiában a Lacus Iuturnae környékéről került elő hasonló, 4. századra datálható pohár vágott, ívelt peremmel, benyomott aljjal, oldalát nem kiszélesedő, négy nagyobb ovális hornyolat díszíti. ${ }^{34}$ A dalmatiai hasonló formájú, benyomott oldalú pohár alja nem megvastagodó, mint a pannoniai daraboknak. ${ }^{35}$

A késő római időszakban üveg Faltenbecherek ritkán fordulnak elő. A díszítésmód létezik, de elsősorban színtelen, vágott peremú tálakon alkalmazzák, ${ }^{36}$ a 4. század első felében szórványosan kisméretú, szögletes testú illatszeres üvegcséken is előfordul. A két pannoniai pohár így kivételnek tekinthető.

A magas, ívelt falú poharak egységes, zárt csoportot alkotnak, darabjaik csaknem kizárólag Arrabonában, Brigetióban, Aquincumban és környékükön kerülnek elő. Ettől délre csupán Pécsett és a környező villák területéről ismert néhány lelet. Egységes méretúek, azonos minőségú és színú alapanyagból készültek. A tárgyak részletkialakítása is megegyezik, egyforma a peremés alikiképzésük. A felsorolt ismérvek alapján megállapítható, hogy a más provinciákban ritkának számító típus Pannonia északi részén, Aquincum, Brigetio és Arrabona térségében a 4. század eleje-közepe táján nagy számban jelenik meg, egységes csoportot alkotva egy múhelykörhöz sorolható (5. kép). Jelenlétük a 4. század első felének leletegyütteseiben jellemző, de néhány pél-

30 PIRLING 1989, Taf. 16.

31 MARTiN 1993, 100, Fig. 1.4-5. A 4. századra datálható olívazöld példányok, formailag megegyeznek, azonban optikai fújtak.

32 Vessberg 1952, Pl. IV.

33 Calvi 1969, Taf. 6.7; Mandruzzato-Marcante 2007, 63, 120. Megegyező, de talpgyúrû́s forma az 1-2. századra datálva.

34 STERNINI 1993, 258, Fig. 16.8.

35 Gregl-Lazar 2008, 111, Pl. 6.2. Az edény az 1-3. századra datálható.

36 STERN 2001, 334. A Római Birodalom nyugati részein népszerúek a benyomott oldalú tálkák vágott durva peremkiképzéssel, rossz, buborékos anyagminőséggel. Germaniában és a Rajna-vidéken, a birodalom keleti részein Moesiától egészen Tunéziáig kimutathatók. dányuk a század második felében, végén is előfordul. ${ }^{37}$

\section{Magas, ívelt falú pohárforma talpgyứứvel (P2 típus) $^{38}$}

$\mathrm{Az}$ előző forma talpgyứrús változata elvétve kerül elő, csupán néhány példát ismerünk (2. kép 6-9). Barkóczi László egy idetartozó leletet említ Brigetióból („43. típus"). ${ }^{39}$ Több előfordulása kimutatható Dél-Pannoniából, Teutoburgiumból, Sirmiumból. ${ }^{40}$ Barkóczi megemlíti, hogy ilyen formájú pohár került elő a Barbaricumból is, az Aquincummal szemközt fekvő részen. ${ }^{41}$

Késő római sírokból tizenkét példánya ismert, kettő-kettő Brigetióból és Sopianaeből, egy-egy Budaörsről, Bátaszék-Kövesdről, Keszthely-Úsztató lelőhelyről, Mórichida-Kisárpásról, Arrabonából és három Aquincumból, a Bécsi úti temetőből származik. ${ }^{42}$

\section{Anyag, méret}

Az anyagminőségük, kidolgozásuk, színük azonos: mind jó minőségú, üvegzöld, sárgászöld és színtelen üvegből készült. Magasság: 7,7-10,8 cm, szájátméró: 6-7,4cm, talpátméró: 3,6-4,4 cm.

\section{Perem- és aljkialakitás}

Peremük ívelt, vágott, durva kialakítású, nem teljesen megmunkált. Aljuk benyomott, enyhén megvastagodó, tartórúd nyomával, vékony, az edény anyagával megegyező plasztikus szálrátét talpgyúrúvel. ${ }^{43}$

\section{Díszités}

Az ívelt falú talpgyưrús poharak általában díszítetlenek, mindössze két kivételt ismerünk (2. kép 7): a Keszthely-Úsztató 10. és a MórichidaKisárpás 3. sírjában talált edény teste, illetve a

\footnotetext{
37 PÉTERFI 1993, 140. sír. Éremleletek alapján a 380-as évek utánra keltezhető

38 DÉVAI 2013, 260-264.

39 BARKÓCZI 1988, 78-79. Brigetióból a 3. század végére, 4. század elejére datálható sírból származik.

40 Šaranović-SveteK 1986, Tab. III; Cermanović-KuzManovič 1979, 32.

41 BARKÓCZI 1998, 78

42 BARKÓCZI 1968, 59-86, 15. sír; TOPÁL 1993, 2., 78., 113, sír; DÉVAI 2012, Kat. Nr. 64-75

43 IsINGS 1957, Form 109c; Goethert-PolascheK 1977, Form $58 \mathrm{a}-\mathrm{b}$.
} 
perem alatti zóna egyszerü, bekarcolt vonallal díszített. ${ }^{44}$

A ritka típus megmunkáltsága, színe, anyagminősége, méretei alapján egy csoportba sorolható a magas, ívelt falú poharakkal. Mindkét típus fó elterjedési területe Pannonia északi része, Arrabona, Brigetio, Aquincum térsége. Szórványos példányok feltúnnek Valeria déli részén, illetve Pannonia Secunda területén. A P1 típushoz hasonlatosan a 4. század első felében és közepén voltak használatban, de néhány darabot még a 4 . század második felében is óriztek. ${ }^{45}$ Pontosan megegyező típust ismerünk Aquileiából, ahol jelenléte a 4 . századra keltezhető. ${ }^{46}$ Idóbeni és térbeni elterjedése lényegében azonos a magas, ívelt falú pohárformával, így valószínúleg egy múhelykörbe sorolhatók (5. kép).

\section{Magas, hengeres testứ pohárforma (P3 típus) ${ }^{47}$}

Barkóczi László katalógusában a talpgyưrúvel ellátott változat (42. típus) szerepel, a talpgyưrü nélküli magas, hengeres testú pohárformát nem tárgyalja. A talpgyúrúvel ellátott variánst a 3. század utolsó és a 4. század elsó évtizedeire keltezi. ${ }^{48} \mathrm{Az}$ egyszerü, hengeres testú pohár a Római Birodalomban a 3. század második felében, a 4. század elején gyakori, de Pannonia Secunda területén nem fordul elő. A birodalom nyugati részén jelen van Augstban a késő 3. századtól a 4. század végéig, függóleges vágott peremmel, benyomott talppal. Sokszor díszítetlen, de előfordul bekarcolt vonaldíszítés, vésett díszítés és az edény testéból kialakított tüskeszerú dekorációo. ${ }^{49}$ Meglévő forma Trierben. ${ }^{50}$ A colchesteri leletek között már a 2. századtól megtalálható díszítetlenül vagy bekarcolt vonaldísszel ellátva. ${ }^{51}$ Ritka az elófordulása Krefeld-Gellep temetójében. ${ }^{52}$ A Római Birodalom keleti felében, Berytusban díszítetlen változatban jelenik meg. ${ }^{53}$ Megfeleltethető: AR 64, Isings 106, T 52, Cool-Price 1995, 68., Fig. 5.3; Jennings 20042005, Fig. 5.7. formáknak. ${ }^{54}$

44 Keszthely: Balatoni Múzeum. Ltsz.: 70.268.1.; Mórichida: Xántus János Múzeum. Ltsz.: 58.1.8.

45 PÉTERFI 1993, 14. sír. A 4. század második felére tehető csakúgy, mint a Keszthely-Úsztató 10. sírjának lelete.

46 MandruzZato-Marcante 2007, 68, Cat. 61.

47 Dévai 2013, 260-264.

48 BARKÓCZI 1988, 78.

49 RÜTTI 1991, Form AR 64, Taf. 64-65.

50 GOETHERT-POLASCHEK 1977, Form 52.

51 COOL-Price 1995, 68, Fig. 5.3.

52 Pirling 1966, TAF. 47, Taf. 17.

53 JENNINGS 2004-2005, Fig. 5.7.

54 RÜTTI 1991, Form AR 64; IsINGS 1957, Form 106; GOETHERTPOlAscheK 1977, Form 52; CoOl-Price 1995, 68, Fig. 5.3; JENNINGS 2004-2005, Fig. 5.7.
A kései pannoniai temetőkben elvétve mutatható $\mathrm{ki}$, összesen tizennégy esetben fordul elő (3. kép 7-8, 4. kép 3). Nyolc díszítetlen és hat díszített variánsa mutatható ki. Győr-Serfóződomb, Mórichida-Kisárpás lelőhelyről egy példány, Pécsről egy, Pátyról és Brigetióból kettő, Savaria Szent Márton utcai temetőjéból egy, Keszthelyről öt darab ismert.

\section{Anyag, méret}

Általános ismertetőjegyük a jó minőség, a buborékoktól, húzódásoktól mentes alapanyag. Színtelen és üvegzöld árnyalatban is fellelhetők. Magasságuk 10,9-10,8 cm, szájátmérő 7,4-8 cm, talpátmérő 3,1-4,2 cm.

\section{Perem- és talpkialakitás}

Peremük függőleges, vágott, durva felszínú, utólag nem polírozott. Négy pohár pereme melegen lekerekített, megvastagodó, ezek közül három Keszthelyről, egy Pécsről került elő. Talpuk enyhén benyomott, nem megvastagodó, tartórúd nyomával. Használatuk a 4. század első felére jellemző, de néhány edény a század második felére datálható. ${ }^{55}$

\section{Díszités}

Díszített változata került elő Győr-Serfőződomb, Mórichida-Kisárpás, Komárom-MOL tartálypark, Keszthely-Fenékpuszta, Keszthely-Dobogó és Savaria, Szent Márton utca lelóhelyekról. ${ }^{56}$ Hat pohár volt díszített, ezek közül csak az egyik keszthelyi példány melegen lekerekített peremú, a többinek a pereme vágott, durva kialakítású, következésképp fóként a vágott peremú variánsokat díszítették. A minta meglehetősen egyszerú, bekarcolt, vízszintesen futó vonalkötegekből áll. Két-két esetben az edény testén egy sávban, illetve az edény peremén és a testén további egy sávban látható a díszítés. Egy-egy esetben pedig a pohár teste két, illetve négy sávban díszített.

A forma jelenlétével Pannoniában a 4. század első és második harmadában számolhatunk. Ritka típus, úgy túnik, hogy a provinciában ezen időszakban inkább az ívelt poharak voltak népszerúek, míg az Imperium Romanum nyugati részén ez a hengeres fajta. Elterjedése a provinciában egyenletes, súrúsödési pontjai nem kimutathatók.

55 Keszthely-Úsztató 1 . és 27. sírja a század második felére tehetó.

56 DÉVAI 2012, Kat. Nr. 82-87; BorHY-SzÁmAdó-BARTUSGELENCSÉr 2007, 51. 


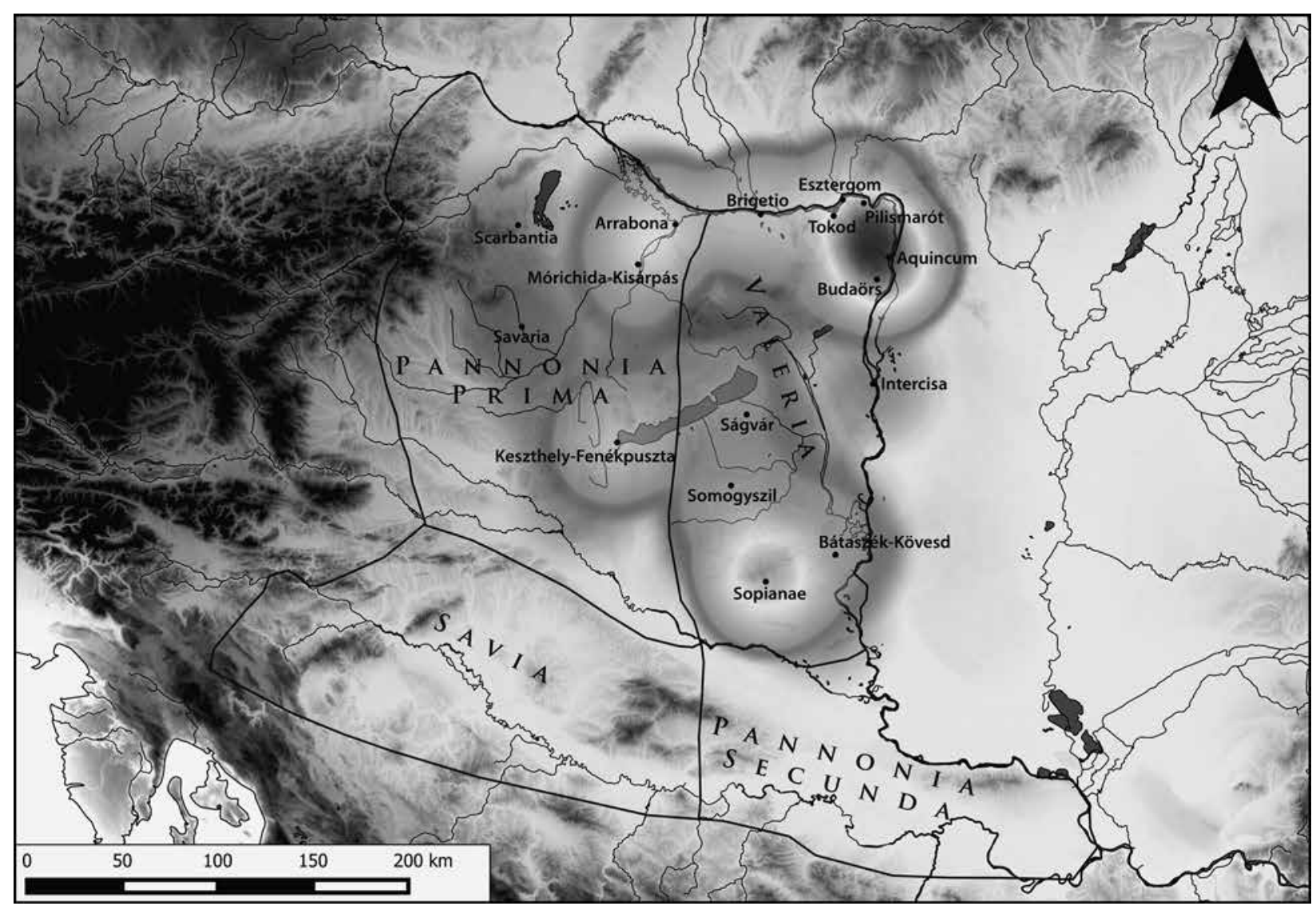

5. kép. A P1-P4 pohárformák elterjedése a késő római Pannoniában 91 tárgy alapján (tervezte: Rupnik László)

Fig. 5. Distribution of glass beakers (P1-P4) in the late Roman Pannonia based on 91 objects (planned by László Rupnik)

\section{Magas, hengeres testú pohárforma talpgyúrúvel (P4 típus) ${ }^{57}$}

Pannoniában a magas, hengeres testú, de vékony, plasztikus szálrátétból képzett talpgyúrúvel ellátott formával gyakrabban találkozunk. A talpgyűrú az edénnyel megegyező alapanyagból készült. Barkóczi László ezt a változatot a 42. típusként határozta meg. Brigetióból és Aquincumból 3. század végi, a 4. század első felére datálható sírokból ismert, kimutatható Sirmiumban is. ${ }^{58}$ Elterjedtsége a Római Birodalom más részein megegyezik az előző típuséval. Egy-egy példa ismert Augstból és Trierből is, ${ }^{59}$ Colchesterben ritka. ${ }^{60} \mathrm{~A}$ keleti birodalomrészen fellelhető a ciprusi üvegleletek között. ${ }^{61}$

A szerző által vizsgált síranyagban huszonhat talpgyúrús, magas, hengeres testú pohár szere-

\footnotetext{
57 DÉVAI 2013, 260-264.

58 BARKÓCZI 1988, 78.

59 RÜTtI 1991, Form AR 63; GOETHERT-POLASCHEK 1977, Form 43

60 CoOL-Price 1995, 69, Fig. 5.3

61 Vessberg 1952, Pl. IV.
}

pel (3. kép 1-5; 4. kép 5-6).62 Mórichida-Kisárpás temetójéból egy, Brigetióból kettô, AquincumBécsi úti temetőből három, Esztergomból a Bánomi-dúlő és a Kossuth utca temetóiből egyegy, Intercisából egy, Pécsről négy, a bátaszékkövesdi temetőből kettő, a pátyi temetőből ugyancsak kettő, a budaörsi temetőből négy, Keszthelyről három, Balatonszentgyörgyről egy és Szombathelyről is egy előfordulásáról tudunk. ${ }^{63}$

\section{Anyag, méret}

Leggyakrabban színtelen, nagyon jó minőségú alapanyagból készültek, kisebb részben üvegzöld és sárgászöld színúek. Méreteik az előző hengeres testú formához hasonlók: magasságuk 10-12 cm, a szájátmérő $5,5-7,2 \mathrm{~cm}$, a talpátmérő $3,1-3,6 \mathrm{~cm}$.

62 Dévai 2012, Kat. Nr. 88-113.

63 BARKÓCZI 1968, 75-105, 3. sírmező, 10. sír; BARKÓCZI 1990 164-166; Topál 1993; Topál 2003, 1., 10., 28. sír; Kelemen 2008, Bánomi-dúlő 172. sír és Kossuth utca 78. sír. 
Perem- és talpkiképzés

Peremük minden esetben függőleges, vágott, durva felszínú, nem eldolgozott. Talpuk enyhén benyomott, nem megvastagodó, tartórúd nyoma látható. Vékony, szabályos, plasztikus szálrátét, talpgyưrúvel ellátott.

\section{Díszítés}

A Barkóczi László katalógusában szereplő üvegek között az egyik brigetiói poháron több sávban egymással párhuzamos, enyhén bekarcolt vonalak figyelhetők meg. ${ }^{64}$ Késő római temetkezésekból mindössze hét díszített darab ismert: az Esztergom-Bánomi-dúlő 172. sírjából származó üvegzöld pohár, egy aquincumi edény, illetve a Barkóczi által is említett, brigetiói sírból származó színtelen darab, egy bátaszék-kövesdi, két keszthelyi és egy szombathelyi pohár. ${ }^{65}$ Minőségüket, alapanyagukat, színüket, méreteiket, megmunkáltságukat tekintve megegyeznek díszítetlen társaikkal. A díszítést bekarcolt sávok alkotják. A brigetiói és a szombathelyi pohár testén két sávban egymással párhuzamos, vízszintesen futó, sekélyen bekarcolt vonaldísz van. A bánomi-dúlói temetőben talált pohár és az egyik keszthelyi darab peremét és további két sávban az edények testét vízszintesen futó, enyhén bekarcolt vonalköteg díszíti. A másik keszthelyi, illetve a bátaszék-kövesdi példányon az edény peremén és testén egy sávban látható ez a díszítés. Ez utóbbi azért is érdekes, mert a szálrátét talpgyứrúje nem tömör, hanem csőszerúen kialakított.

Megjelenése a 4. század első harmadára tehető, használata a 4. század második harmadában is folytatódott. A pohártípus elterjedtsége alapján Pannonia egész területén népszerú volt.

\section{Összegzés}

A fent bemutatott négy pohártípus Pannoniában és a Római Birodalom más területein egyaránt a 3. század végén, a 4 . század elején túnik fel. A karcsú, magas, nagy úrtartalmú formák részben felváltják a korábban népszerú szélesebb, csészeszerú típusokat. Többségük egyszerú, alig vagy egyáltalán nem díszített, hétköznapi használati tárgynak tekinthetó. A korszak temetkezéseiból a tárgyalt poharak sorozata ismert. A nagy esetszám lehetóséget nyújt a forma elterjedésének vizsgálatára.

Pannoniában elsősorban az ívelt falú, kihajló szájperemú edényeket kedvelték, míg a birodalom más részein az egyszerú hengeres testú poharak dominálnak. Az ívelt falú forma Pannoniától délre, Dalmatia területéról is ismert. Az ívelt falú üvegek talpgyúrüs változatai kevésbé voltak kedveltek. A hengeres testú, függőleges peremú típus egyszerúbb, talpgyưrú nélküli változata ritkább, a talpgyứrüs variáns az elterjedtebb. A négy forma egységes, zárt csoportot alkot, darabjai Arrabona, Brigetio és Aquincum körül csoportosulnak, csaknem kizárólag ezeken a lelőhelyeken és környékükön kerülnek elő. Ettől délre csupán Pécsett és a környező villák területén találhatók meg, de sokkal kisebb számban (5. kép). Egységes méretúek, azonos minőségú és színú alapanyagból készültek. A tárgyak részletkialakításának technikája is megegyezik, egyforma a perem- és talpkiképzésük. Ezen érvek alapján a négy típust egy múhelykör termékeinek tarthatjuk, amely Pannonia üvegmúvességét egy rövidebb időszakban, a 3. század végén, a 4. század elején jellemezte. Az összes késő római ivóedényformával összevetve ${ }^{66}$ a bemutatott négy típus elterjedésének egyértelmúen kirajzolódó súlypontja a limes menti települések Arrabonától Aquincumig terjedő szakasza.

\section{IRODALOM}

BARKÓCZI, LÁSZLÓ

1961 Adatok Brigetio későrómai történetéhez. Folia Archaeologica (Budapest) 13, 95-115.

1968 Die datierten Glasfunde aus dem 3.-4. Jahrhundert von Brigetio. Folia Archaeologica (Budapest) 19, 59-86.

1988 Pannonische Glasfunde in Ungarn. Studia Archaeologica 9. Budapest.

BORHY LÁSZLÓ-SZÁMADÓ EMESE-BARTUS DÁVID-GELENCSÉr ÁKOS

2007 Ujjabb késő római kőládasír Brigetio Gerhát-temetőjéből. In: Régészeti Kutatások Magyarországon. Budapest 2008, 51-61.

64 BARKÓCZI 1988, Kat. Nr. 85.

65 DÉvai 2012, Kat. Nr. 106-112.
66 DÉvAi 2013, 265-266. A késő római időszakban Pannoniában elsősorban asztali használatra szánt edényeket gyártottak, a vizsgált tárgyak 57,9\%-a ebbe a kategóriába sorolható. Ezen belül is uralkodó a pohár, az összes edény 45,5\%-át (453 példány) teszik ki. 
BudAi-BALOGH TiBOR

2008 Beszámoló a katonaváros nyugati temetójében végzett kutatásokról. Aquincumi Füzetek (Budapest) 14, 40-56.

DÉVAI, KATA

2012 Késő római temetkezések üvegmellékletei Pannoniában. Doktori disszertáció. ELTE BTK. Kézirat. Budapest.

2013 Glass Vessels from Late Roman Times Found in Graves in the Hungarian Part of Pannonia. Dissertationes Archaeologicae (Budapest) 3/1, 259-274.

DÉvAI KATA-GELENCSÉR Ấos

2012 Római kori lakóház és üveggyártó múhely Brigetióban. In: Bíró Sz.-Vámos P (szerk.): FIRKÁK II. Fiatal római koros kutatók II. konferenciakötete. Fiatal Római Koros Régészek IV. Konferenciája. Győr, 439468.

CALVI, Maria C.

1969 Die roemischen Glaeser. Museum von Aquileja. Aquileja.

CERMANOVIĆ-KuZMANOVIČ, AlEKSANDRINA

1974 Pregled i razvitak rimskog stakla u Crnoj Gori. Archeološki Vestnik (Ljubljana) 25, 175-190.

COOL, Hilary E. M.-PRICE, JENNIFER

1995 Roman Vessel Glass from Excavations in Colchester, 1971-1985. Colchester Archaeological Report:

Colchester Archaeological Trust (Colchester) 8.

1997 Il vetro, Transparenze imperiali. Vetri romani dalla Croazia. Milano.

GOETHERT-POLASCHEK, KARIN

1977 Katalog der römischen Gläser des Rheinischen Landesmuseums Trier. Mainz am Rhein.

GREGL, ZORAN-LAZAR, IRENA

2008 Bakar. Staklo iz rimske nekropole. The Glass from the Roman Cemetery. Zagreb.

HARDEN, DONALD B.

1936 Roman Glass from Karanis. Found by the University of Michigan Archaeological Expedition in Egypt, 1924-29. Oxford.

ISINGS, CLASINA

1957 Roman Glass. Groeningen/Djakarta.

JENNINGS, SARAH

2004-2005 Vessel Glass from Beirut. Bey 006, 007 and 045. Berytus (Beirut) 48-49.

H. KELEMEN MÁRTA

2008 Solva. Esztergom későrómai temetői. Libelli Archaeologici Ser. Nov. No. III. Budapest.

VAN LiTH, SOPHIA M. E.-RANDSBORG, KLAUS

1985 Roman Glass in the West: A Social Study. Berichten van de Rijksdienst voor het Oudheidkundig Bodemonderzoek (Amersfoort) 35, 413-533.

MandruZzato, LuCiAnA-Marcante, Alessandra

2005 Vetri Antichi del Museo Archeologico Nazionale di Aquileia. Corpus delle Collezioni del Vetro in Friuli Venezia Giulia 2. Venezia.

MARTIN, CHANTAL

1993 Le verre de l'Antiquité tardive en Valais, notes préliminaires. In: D. Foy (red.), Le verre de l'antiquitté tardive et du haut moyen âge. Typoligie-Chronologie-Diffusion. Association Française pour l'Archéologie

V. PÉTERFI ZSUZSA du Verre, 8me rencontre, (Guiry-en-Vexin), 93-109.

1993 A Bátaszék-Kövesd pusztai későrómai temető. A Wosinsky Mór Múzeum Évkönyve (Szekszárd) 18, 47-168.

PiRLing, RENATE

1966 Das römisch-fränkische Gräberfeld von Krefeld-Gellep. Berlin.

1989 Das römisch-fränkische Gräberfeld von Krefeld-Gellep 1966-1974. Stuttgart.

RuŽIĆ, MiRA A.

1994 Rimsko staklo u Srbiji. Centar za arheološka istraživanja 13. Beograd.

RÜTTI, BEAT

1991 Die römischen Gläser aus Augst und Kaiseraugst. Forschungen in Augst (Augst) 13.

SAKL-OBERTAHLER, SYLVIA-TARCSAY, KINGA

2001 Römische Glasformen aus Wien. Fundort Wien. Berichte zur Archäologie (Wien) 4, 78-112.

ŠARANOVIĆ-SVETEK, VESNA

1986 Antičko staklo u Jugoslovenskom delu provincije donje Panonije. Novi Sad.

STERN, MARIANNE E.

2001 Römisches, byzantinisches und frühmittelalterliches Glas. 10 v. Chr.-700 n. Chr. Sammlung Ernesto Wolf. H. n. 


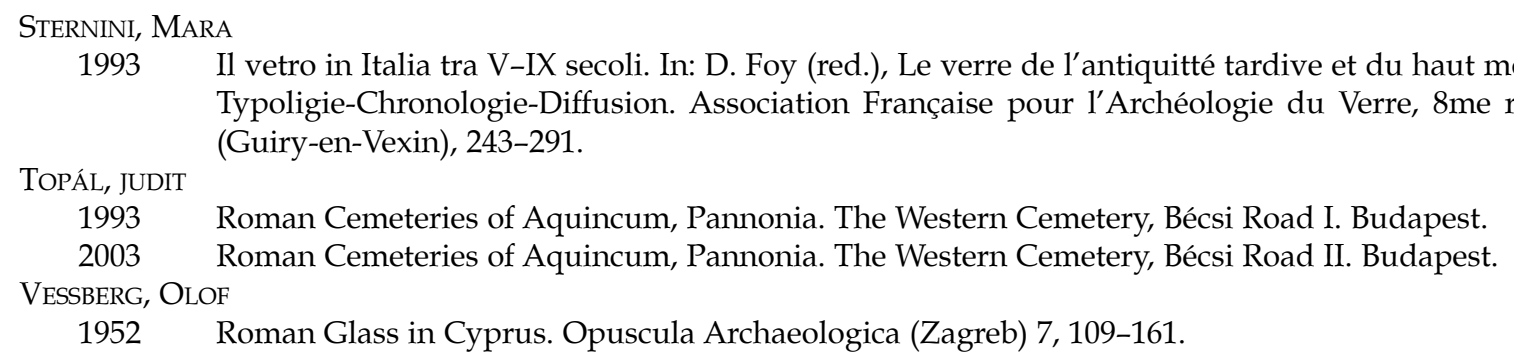

SLIM BEAKERS FROM LATE ROMAN TIMES FOUND IN GRAVES IN PANNONIA

\section{KATA DÉVAI}

The discussed era is the peak period of glass practice in Pannonia as a remarkable amount of vessels occurred then including whole series of each type, which were colourful and various. They provided perfect subjects for the analysis. From the end of the $3^{\text {rd }}$ century comparing to the previous ones, bigger and more practical and applicable forms spread across the province. However, from the end of the $3^{\text {rd }}$ century to the end of the $5^{\text {th }}$ century numerous tendencies caused differences, of which the depiction and analysis are one of the main aims. From the end of the $3^{\text {rd }}$ century, bulks of glass vessels appeared, which were tall and useful regarding their size and varied regarding their types. Tall cups, flasks and jugs dominated in this period, whereas storage and transport vessels and unguentariae were inferior. The raw materials of these were good quality and colourless glass was the primary shade used until the end of the $4^{\text {th }}$ century. The forms were simple and sophisticated containing little decoration. However, parts of these vessels were refined and thoroughly elaborated. This period reflects that glass products were easily accessible for every household. They weren't luxurious items but ordinary objects for daily usage.

Slim beakers with curving body, slim beakers with curving wall and a base ring, slim, cylindrical beakers and slim, cylindrical beakers with a base ring can be related to one workshop on the grounds of their same qualities, colours, measures, decorations, rims, and their chronological and geographical spread. The workshop may have operated at the end of the $3^{\text {rd }}$ century $\mathrm{AD}$, or rather in the first half of the $4^{\text {th }}$ century AD. These forms particularly occurred in the vicinity of Arrabona, Brigetio and Aquincum in this short period of time. In Pannonia these cups are made of colourless glass with a good quality and they are partly decorated, sometimes including abrasion bands, and their rims are usually cracked-off and unpolished. These types are more typical in the first two-thirds of the $4^{\text {th }}$ century AD. 